\title{
Erratum to: Methyl donors potentiates growth, metabolic status and neurotransmitter enzyme in Labeo rohita fingerlings exposed to endosulfan and temperature
}

\author{
Neeraj Kumar • S. B. Jadhao • N. K. Chandan • \\ Md. Aklakur $\cdot$ R. S. Rana
}

Published online: 23 May 2012

(C) Springer Science+Business Media B.V. 2012

\section{Erratum to: Fish Physiol Biochem \\ DOI 10.1007/s10695-012-9622-4}

There is a change in the authorship of the article since the original publication. The complete and correct author group should read as:

Neeraj Kumar $\cdot$ S. B. Jadhao $\cdot$ N. K. Chandan $\cdot$ Md. Aklakur · R. S. Rana

The first line of the "Neuro-transmission enzymes" section in Results and Discussion is published incorrectly. The correct line should read as: "Data pertaining to the impact of dietary methyl donors on AChE activity in the brain tissue of $L$. rohita fingerlings exposed to endosulfan-induced chronic stress is shown in Fig. 1b."

Inadvertently, the complete acknowledgment was not included in the original publication. The complete acknowledgement should read as: "Authors are thankful to Dr W. S. Lakra, Vice Chancellor/Director, Central Institute of Fisheries Education, Mumbai-61 for providing all the facilities required for the present work. The first author acknowledges the financial assistance in the form of Junior Research Fellowship from the Institute and help and encouragement from A. K. Jha, Kundan Kumar, Md Akhtar and Saurav Kumar".
The online version of the original article can be found under doi:10.1007/s10695-012-9622-4.

N. Kumar $(\bowtie) \cdot$ S. B. Jadhao · N. K. Chandan .

Md. Aklakur · R. S. Rana

Central Institute of Fisheries Education (CIFE),

7-Bungalows, Versova, Andheri (W),

Mumbai 400061, India

e-mail: neeraj_journal@live.in 